\title{
Tikimybinis energetinio saugumo vertinimas. Kauno šilumos tiekimo rinkos analizè
}

\author{
Juozas Augutis, \\ Vaida Matuzienè \\ Lietuvos energetikos institutas, \\ Breslaujos g. 3, LT-44403, Kaunas \\ El.paštas: juozas@mail.lei.lt; \\ vaida@mail.lei.lt.
}

Straipsnio tikslas yra pristatyti sukurtą tikimybinę energetinio saugumo metodiką, kuri leidžia analizuoti ịvairių rizikų (techninių, ekonominių, socio-politinių) pasekmių ịtaką energetiniam saugumui.

Pateikta metodika yra dviejų dalių: trikdžio formavimosi iš grèsmès modelis ir sutrikdytos energetikos sistemos vystymosi modelis.

Skaičiavimai atliekami remiantis tikimybinès saugos analizès metodais.

Straipsnyje pateiktas bendras energetikos sistemos modelis, paaiškinti jo koncepcijos elementai (grèsmės realizacija, trikdis, barjeras, pasekmè), îvesti energetikos sistemos pasekmių po grèsmès realizacijos vertinimo rodikliai.

Sukurtos metodikos demonstracijai pasirinkta $\mathrm{AB}$ „Kauno energija“. Išnagrinèti keli hipotetiniai sistemos plètros scenarijai esant vienam trikdžiui - visiškai nutraukus dujų tiekimą. Scenarijai apima ịvairius šilumos gamybos būdus - tiek Kauno termofikacinès elektrinès rekonstrukciją, tiek ir biokuro katilinių statybą. Naudojantis sukurta technologija, ịvairūs Kauno šilumos tiekimo plètros scenarijai palyginti tarpusavyje, parodytas laisvos šilumos gamybos rinkos privalumas.

Raktažodžiai: energetika, energetinis saugumas, tikimybinè analizė

\section{IVADAS}

Tikimybinio energetinio saugumo tyrimo tikslas yra pateikti metodiką, kuri ịvertintų įvairių rizikų (techninių, ekonominių, socio-politinių) itaką stabiliam energijos tiekimui priimtinomis kainomis ir atlikti šių rizikų potencialiai keliamų pasekmių analizę. Vertinant energijos tiekimo saugumą ilgu laikotarpiu, analizuojama naujų energetikos infrastruktūrų ịtaka energetikos sistemos funkcionavimui, alternatyvių energijos gamybos ir tiekimo šaltinių panaudojimo galimybès. Be to, pastaruoju metu viena aktualiausių energetikos temų - jos plètra. Šia tematika diskutuoja tiek mokslininkai, tiek energetikai, politikai ir politologai. Priimant sprendimus, reikalinga įvertinti skirtingas aplinkas: technologines, ekonomines, socio-politines, geopolitines; atsižvelgti ị kylančias grésmes, jų galimus sukelti trikdžius, pasekmes.

\section{ENERGETINIO SAUGUMO METODŲ APŽVALGA}

Literatūros šaltiniuose pateikiamos energetinio saugumo studijos dažniausiai vertina tam tikrus energetinio saugumo aspektus: kuro šaltinių diversifikaciją [1], ekonominių kaštų analizę [2], politinių-politologinių grèsmių tyrimus $[3,4]$, îvairių indikatorių sistemų sudarymą [5-7]. Tikimybiniai metodai vertinant energetinį saugumą iki šiol nèra plačiai taikomi. Tikimybinių metodų taikymo pradžia yra siejama su darbu, kuriame buvo atliktas ịvairių energijos rūšių palyginimas [8].

Nors skelbiamų energetinio saugumo analizès studiju daugejja, kol kas nèra visus galimus trikdžius bei jų ittaką energetikos sistemai vertinančios metodikos.

Šiame metodologiniame darbe energetiniam saugumui tirti siūloma taikyti tikimybinę rizikos analizę (TRA, angl. 
Probabilistic Risk Assessment). Tai vienas iš metodų, dažniausiai naudojamų atliekant sudètingų techninių sistemų rizikos vertinimą. Pirmą kartą išsami tikimybinè rizikos analizė buvo atlikta $1975 \mathrm{~m}$. JAV ir žinoma kaip reaktorių saugos studija [9]. Nuo šios pradinès studijos, TRA metodai buvo gerokai patobulinti ir TRA tapo standartine branduolinių reaktorių ir kitų sudètingų techninių sistemų saugos vertinimo priemone.

Naudojama kartu su kitais deterministiniais modeliais, ši analizè gali ịvertinti didelį kiekị ịvairių energetikos sistemos avarijų scenarijų ir jų pasekmių. Labai svarbu įvertinti ilgalaikių trikdžių sukeltų sunkių pasekmių šalies energetiniam saugumui tiketinumą. Taip pat svarbu palyginti sunkių pasekmių tiketinumą, igyvendinus ịvairias planuojamas energetinio saugumo priemones.

Darbe pateikti Kauno aprūpinimo šiluma sistemos plètros scenarijai parodo metodikos galimybes, palyginti įvairūs energetinio saugumo scenarijai, ịvertinta laisvosios rinkos ittaka energetiniam saugumui.

\section{TIKIMYBINIO ENERGETINIO SAUGUMO VERTINIMO ANALIZE்}

Energetinio saugumo sąvoka turi labai daug apibrěžimų:

- tai galimybé naudotis energija ịvairiomis jos formomis bet kuriuo metu ir pakankamais kiekiais bei priimtinomis kainomis (Tarptautine energetikos agentūra);

- energetikos sistemų patikimumas, užtikrinantis ekonomikos augimą ir energijos šaltinių tiekimo stabilumą (Pasaulio energetikos taryba);

- šalies energetinė nepriklausomybė ir galimybè dalyvauti energijos rinkose, bendra išorinès energetikos politika (Europos Komisijos „Žalioji knyga“).
Energetinio saugumo sąvokos apibrèžimuose išskiriamas energijos tiekimo užtikrinimas nepadidejusiomis (atitinkančiomis natūralų ekonomikos augimą) kainomis. Galutinès energijos netiekimas ir/ar jos kainos padidejimas yra energetinio nesaugumo rodikliai.

Pristatomos energetinio saugumo tikimybinès vertinimo metodikos pagrindą sudaro galimų grèsmių energetiniam saugumui vertinimo ir galimų sutrikimų tikimybinio vertinimo modeliai, kai iš grèsmių realizacijos susiformuoja trikdžiai, o iš jų - galutinès būsenos / pasekmès (apsirūpinimo energijos ištekliais patikimumas už normalią arba padidejjusią kainą). Normalia kaina laikoma vidutinè esama arba prognozuojama modeliuojamo laikotarpio kaina. Tikimybinè energetinio saugumo analizės schema pateikiama 1 pav.

Pagrindinius energetinio saugumo analizès etapus sudaro:

- grėsmių identifikavimas, kai nustatomos grėsmės ir pavojingi ivvykiai, galintys sukelti kuro tiekimo sutrikimus ar tam tikros pirminès energijos rūšies kainos padidejimą;

- prevenciniai barjerai, t. y. techniniu ir organizaciniu priemonių, mažinančiu grèsmių realizacijos poveiki, nustatymas ir jų patikimumo vertinimas;

- trikdžiai (nutrūkęs kuro ar energijos tiekimas, padidëjusi kaina), kylantys dèl grèsmių realizacijos, jų modeliavimas ir analizé;

- saugos barjerai, t. y. nustatomos šalies ar regiono aprūpinimo energija alternatyvos, įvertinami turimi rezervai ir jų patikimumo analizè;

- sutrikdytos energetikos sistemos modeliavimas ir ju pasekmių analizè. Analizuojami avariniai scenarijai, kai kuro tiekimo nutraukimas reikalauja alternatyvaus aprūpinimo pirmine energija ar/ir rezervinių jègainiu ịsijungi-

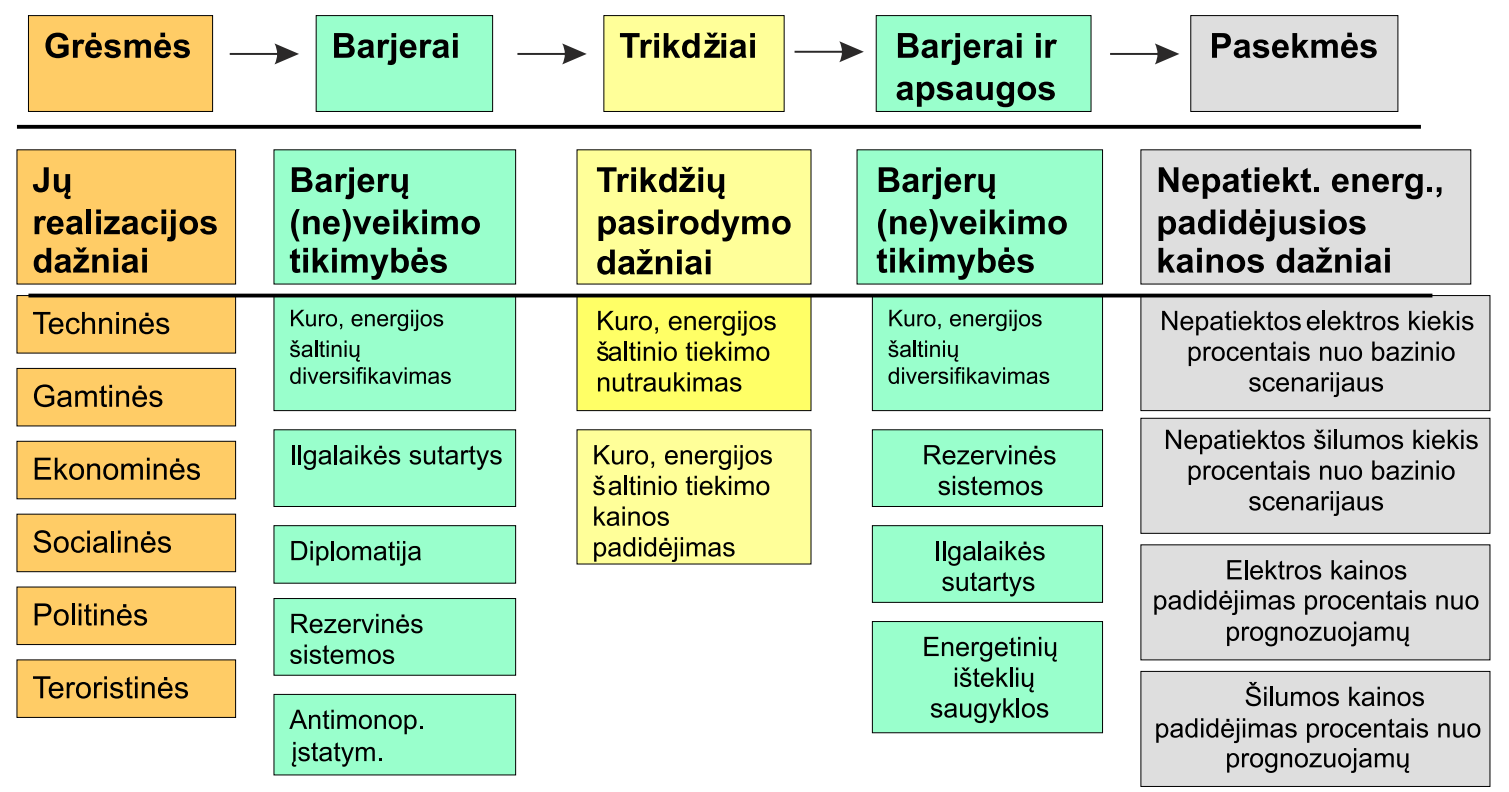

1 pav. Tikimybinè energetinio saugumo analizés schema 
mo ị galutinès energijos gamybą arba papildomą galutinès energijos importą. Analizè atliekama naudojant vieną iš TRA technologijų (atskiras Markovo metodų atvejis), kai modeliuojami galimų ịvykių bei gedimų medžiai. Šiame etape ịvertinami energijos netiekimo bei kylančios kainos dažniai.

Modelio ịvykių medžiai yra dviejų tipų. Pirmojo tipo medžiai skirti formuluoti scenarijams, kai numatomos grèsmių pasekmės: energetikos sistemos trikdžiai - kuro / energijos šaltinio tiekimo nutraukimas ar kainos padidejjimas. Antroji ịvykių medžių grupė skirta modeliuoti sutrikdytos energetikos sistemos scenarijų, kur nagrinëjama jau trikdžiais paveiktos energetikos sistemos energijos gamyba naudojant alternatyvius kuro variantus.

Prieš sudarant modelị reikia išnagrinèti bendrus energetikos sistemoje vykstančius procesus bei egzistuojančias priklausomybes ir numatytus saugos barjerus. Ivykus pradiniam sistemos trikdžiui, susidaro visa ịvykių grandinė, kurioje ypač svarbų vaidmenị vaidina įvairūs prevenciniai ir saugos barjerai: alternatyvusis kuras, saugyklos ir pan.

Pirmiausia aptarsime elementus, darančius ịtaką energetiniam saugumui.

Grèsmès realizacija - tai pradinis bet kokios prigimties (techninès, teroristinès, gamtinės, socio-politinės, ekonominès) îvykis, potencialiai galintis sutrikdyti energetikos sistemos ar jos dalies funkcionavimą ir sukelti nepageidaujamų pasekmių. Tai gali būti avarijos dèl techninių, teroristinių ar gamtinių priežasčių, neigiama monopolijų veikla, politiniai ịvykiai, veikiantys ị šalį tiekiamą kuro ar energijos importą ir t. t.

Prevencinis barjeras - tai organizacinis (priklausomai nuo grèsmès realizacijos pobūdžio: techninis, socio-politinis, ekonominis) veiksmas, galintis sumažinti ar visiškai panaikinti grèsmès realizacijos keliamą riziką. Pvz., prevenciniai barjerai (esant ilgalaikei techninei avarijai) gali būti laikinos tiekimo linijos ar rezervinés tiekimo alternatyvos, politinius ar ekonominius sprendimus gali paveikti ịvairūs istatymai, sutartys, diplomatiniai veiksmai.

Energetikos sistemos trikdis - tai po grèsmès realizacijos susiformavę energetikos sistemos pokyčiai, turintys itakos šalies ar regiono energetiniam saugumui. Dažniausiai tai yra visiškas arba iš dalies kuro ar pirminès energijos tiekimo nutraukimas, akivaizdžiai padidejusi kaina. Šiame darbe nagrinèjami ilgalaikiai energetikos sistemos plètrai itakos turintys trikdžiai.

Saugos barjeras - tai techninių ar/ir organizacinių priemonių visuma, padedanti sumažinti ar visiškai panaikinti trikdžio keliamą žalingą poveikị sistemai. Saugos barjerai padeda užtikrinti alternatyvų aprūpinimą energija. Tai energijos gamyba rezerviniu kuru ar/ir rezervinèse jègainèse, energijos importas ir pan.

Nepriimtinos pasekmès - tai galutinès energijos tiekimo sutrikimas ir / ar gerokai padidejusi tiekiamos energijos kaina, palyginti su prognozuojama kaina (\%). Šiame darbe nenagrinèjama žala dèl šių pasekmių.

Tarkime, kad turime $n$ grèsmių realizacijų, kurios sudaro aibę $\{G\}=\left(g_{1}, g_{2}, \ldots, g_{n}\right)$. Panagrinèkime atskirą $i$-os grèsmès realizaciją $g_{i}$ (2 pav.). Ši grèsmès realizacija gali sukelti įvairių sistemos trikdžių, tačiau trikdžių nulemtos pasekmès ir jų dydis didžia dalimi priklauso nuo egzistuojančių prevencinių ir saugos barjerų.

Esant grèsmès realizacijai, prevencinio barjero tikslas yra užtikrinti, kad sistemos trikdis nebūtų sukeltas ir nebus nepageidaujamų pasekmių. Jei prevencinis barjeras negali neutralizuoti grèsmès - kyla trikdis, kuris energetikos sistemoje gali sukelti kritinių ịvykių eigą, galinčią baigtis

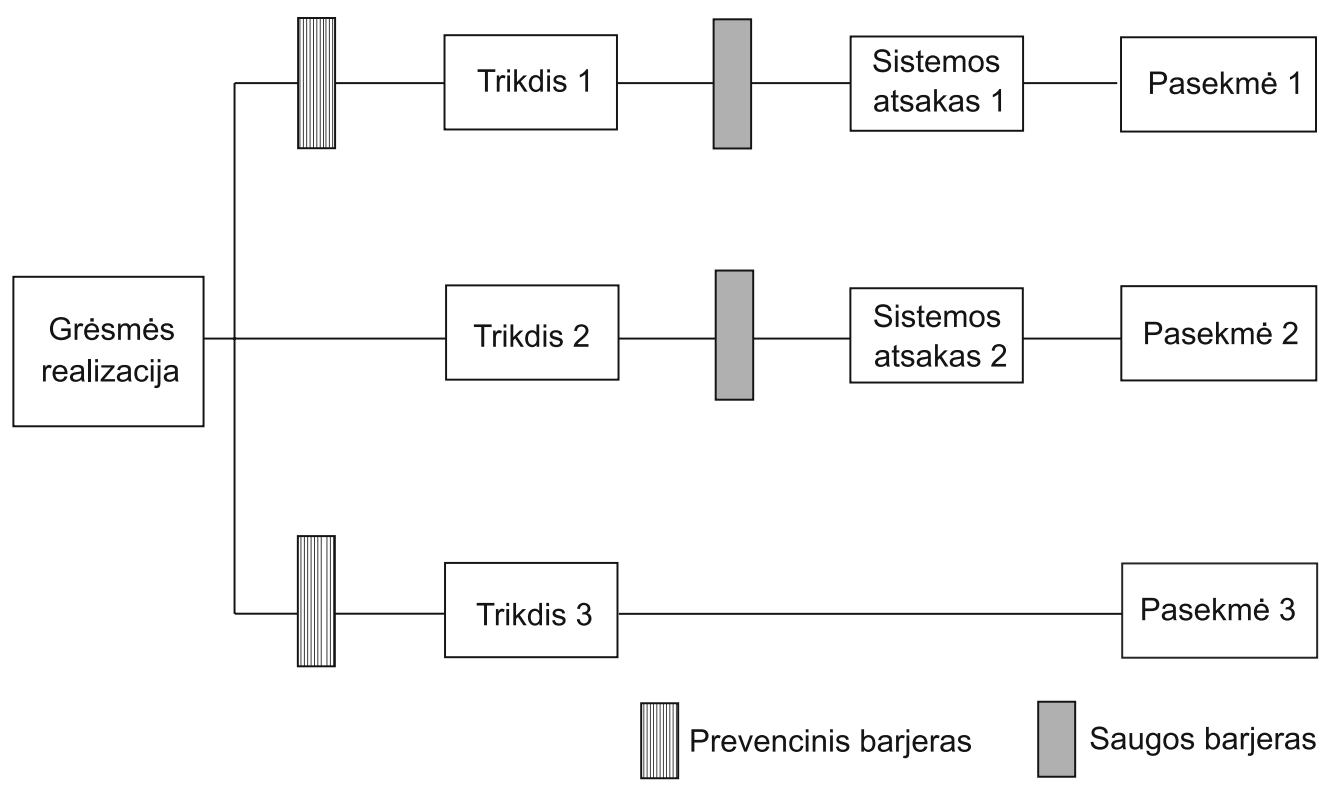

2 pav. Jvykių eiga dèl grésmés realizacijos 


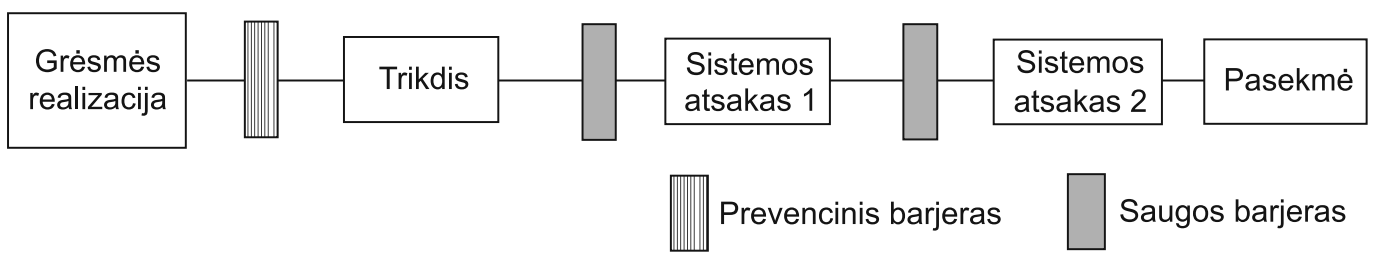

3 pav. Grèsmės realizacijos inicijuota įvykių eiga

nepageidaujamomis pasekmėmis. Tolimesné įvykių eiga priklauso nuo energetikos sistemoje numatytų saugos barjerų.

Kiekvieną galimą ìvykių eigą pavadinkime trikdžio vystymosi ar pasekmès formavimosi (priklausomai nuo i̇vykių medžio tipo) scenarijumi. Jei daroma prielaida, kad dèl sèkmingos prevencijos ar suveikus saugos barjerui energetikos sistemoje kilę trikdžiai ar kritiniai ịvykiai visiškai neutralizuojami, tuomet avarinis scenarijus baigiasi be pasekmių.

Siekiant kiekybiškai įvertinti bendrą grèsmių realizacijų keliamą riziką, būtina nagrinèti atskirus avarijų scenarijus (3 pav.).

Tarkime, kad turime galimų avarinių scenarijų aibę $\{S\}=\left(s_{1}, s_{2}, \ldots, s_{k}\right)$. Kiekvieną scenarijų sudaro tam tikri ịvykiai, kurie gali būti dviejų būsenų: ịvykis ịvyko arba neịvyko. Tuomet $i$-ąji scenarijų galime aprašyti lygtimi:

$$
s_{i}=F \wedge \bar{G}
$$

čia $F$ yra funkcija, aprašanti sẻkmingai veikiančias saugos sistemas (barjerus), t. y. sẻkmingai ịvykusių j̣vykių loginè sandauga:

$$
F=f_{1} \wedge f_{2} \wedge \ldots \wedge f_{k}=\bigcap_{i=1}^{k} f_{i}
$$

$\bar{G}$ charakterizuoja nesėkmingai veikiančias saugos sistemas, t. y. neivivkusių ivvykių loginè suma:

$$
\bar{G}=\overline{g_{1}} \wedge \overline{g_{2}} \wedge \ldots \wedge \overline{g_{n}}=\overline{g_{1} \vee g_{2} \vee \ldots \vee g_{n}}
$$

Eigos scenarijaus tikimybė su sąlyga, kad grèsmė įvyko, išreiškiama lygtimi:

$$
P(S \mid I)=P(F \cap \bar{G})=P(F) P(\bar{G})=P(F)(1-P(G)) .
$$

Tuo atveju, jei energetikos sistemoje nèra numatyta saugos barjerų:

$$
\{F\}=\{G\}=\{\} \text { ir } P(S \mid I)=1 \text {. }
$$

2 pav. parodyta, kad po grèsmès realizacijos galimi įvairūs įvykių scenarijai. Tačiau reikia pastebèti, kad visi scenarijai yra tarpusavyje nesuderinami:

$$
P\left(s_{i} \cap s_{j}\right)=0, \forall i, j ; i \neq j .
$$

Turẻdami atskirų eigų scenarijų tikimybes, galime ịvertinti tikimybę, kad, realizavus grèsmę, vyks avarinis scenarijus su nepriimtinomis pasekmèmis, t. y. šios tikimybès ivvertinimui reikia nustatyti bet kurio eigos scenarijaus pasirodymo tikimybę. Pritaikius elementarius tikimybių teorijos dèsnius, gaunama ši išraiška:

$$
\begin{aligned}
P\left(\bigcup_{i=1}^{n} s_{i}\right)= & \sum_{i=1}^{n} P\left(s_{i}\right)-\sum_{i<j} P\left(s_{i} \cap s_{j}\right)+\sum_{i<k<k} P\left(s_{i} \cap s_{j} \cap s_{k}\right)+\ldots \\
& +(-1)^{n+1} P\left(s_{1} \cap s_{2} \cap \ldots \cap s_{n}\right) ;
\end{aligned}
$$

čia atskiro scenarijaus $s_{i}$, sudaryto iš $t$ ịvykusių ịvykių $E_{1}, E_{2}$, ..., $E_{t}$ ir $k$ neịvykusių ìvykių, tikimybė $P\left(s_{i}\right)$ apskaičiuojama remiantis (7) išraiška, t. y.:

$$
\begin{aligned}
& P\left(s_{i}\right)=P\left(E_{1} \cap E_{2} \cap \ldots \cap E_{t} \cap \overline{U_{1}} \cap \overline{U_{2}} \cap \ldots \overline{U_{k}}\right)= \\
& =P\left(E_{1}\right) P\left(E_{2}\right) \cdots P\left(E_{t}\right) P\left(\overline{U_{1}}\right) P\left(\overline{U_{2}}\right) \cdots P\left(\overline{U_{k}}\right)= \\
& =P\left(E_{1}\right) P\left(E_{2}\right) \cdots P\left(E_{t}\right)\left(1-P\left(U_{1}\right)\right)\left(1-P\left(U_{2}\right)\right) \cdots\left(1-P\left(E_{t}\right)\right) .
\end{aligned}
$$

Tokia tikimybių skaičiavimo metodika taikoma vertinant tiek trikdžių, tiek pasekmių tikètinumą.

\section{ENERGETIKOS SISTEMOS TIKIMYBINIS SAUGUMO MODELIS}

Pateiktą eigų pasekmių skaičiavimo technologiją perkelsime ị energetikos sąvokas.

Energetikos sistemos grèsmès gali realizuotis kiekviename energetikos sektoriuje (naftos, dujų, elektros, atsinaujinančių išteklių ir kt.), tačiau šalies energetikos sistemoje labiausiai pavojingomis galima laikyti grèsmes, apimančias kurą ar energiją, kurie yra šalyje naudojami kaip pagrindiniai, o ne rezerviniai, ir sudaro didelę vartojimo balanso dali. Taip pat labai pavojingais galima būtų laikyti mažai tikètiną atveji, kai sutrikdomas dviejų alternatyvių pirminès energijos rūšiu tiekimas. Grèsmių tikètinumas ar dažniai - vienas iš rizikos matų. Siekiant įvertinti grèsmių realizavimosi tikimybę, būtina atsižvelgti ị grèsmių šaltinių savybes (pvz., galimas gamtos stichijas ir jų padarinių riziką) bei motyvus (pvz., vienintelio gamtiniu dujų tiekèjo interesus didinti dujų kainas importuojančioms valstybėms; nutraukti dujų tiekimą dèl politinių, o ne ekonominių motyvų). 


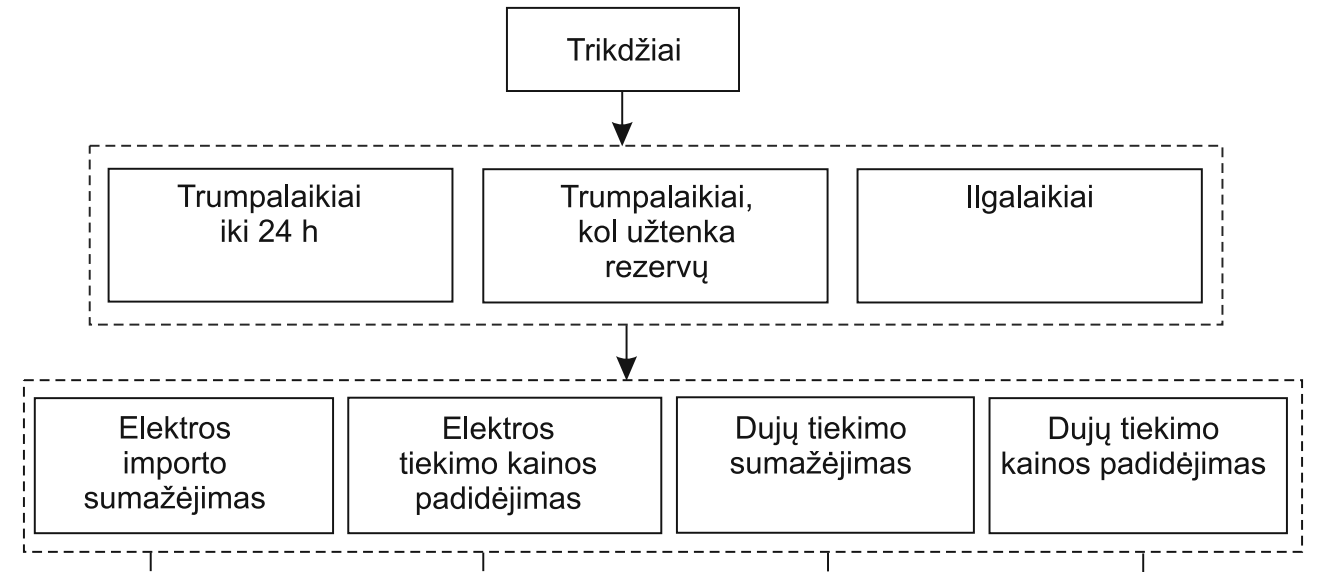

4 pav. Energetikos sistemos trikdžių klasifikacija

Nuo tam tikro pirminès energijos ar kuro tiekimo ir didejjančių kainų saugo ịvairaus pobūdžio barjerai. Tikimybinëje analizėje jie vadinami funkciniais ịvykiais. Barjerai, priklausomai nuo to, kuri grèsmé realizuojasi, gali būti: rezervinès tiekimo / gamybos sistemos; alternatyvaus tiekimo; laikinos linijos / vamzdynų; teisinès antimonopolinès; politinès šalies ar didesnio regiono priemonès.

Iš grèsmių realizacijos susiformavę trikdžiai gali būti trumpalaikiai arba ilgalaikiai (4 pav.). Energetinio saugumo tyrimų objektas - ilgalaikiai trikdžiai. Todèl nagrinèjami trumpalaikiai trikdžiai, kurie tęsiasi ne trumpiau 24 val. ir trunka tol, kol užtenka nutraukto energijos šaltinio resursų (pagal ịstatymus - 60-90 dienų), ir ilgalaikiai trikdžiai - tokie, kai resursai jau išnaudoti, tenka pasitelkti alternatyvaus kuro gamybą, papildomus gamybos pajègumus. Trikdžiai gali būti skirtingo lygio: energijos netiekimo dydị tikslinga numatyti tiksliau (modelyje jis numatomas kas $10 \%$ ), kainų padidejimas gali būti apibrežiamas grubiau (kas $25 \%$ ). 4 pav. parodyti galimi pagrindiniai Lietuvos energetikos sistemos trikdžiai.

5 pav. pateiktas Lietuvos ịvykių medžio pavyzdys, kuriame modeliuojamas ilgalaikis $100 \%$ dujų nutraukimas dèl geopolitinių priežasčiu su šalimi tiekèja. Po inicijuojamo ìvykio vienas po kito logine tvarka išdèliojami galimi prevenciniai barjerai (pvz., Lietuvos diplomatinès derybos dèl $100 \%$ dujų tiekimo atstatymo), saugantys, kad nesiformuotų trikdžiai.

Taigi iš aptartų grèsmių realizacijos medžių gaunama ịvykių ir gedimų trikdžių aibè ir tų trikdžių tikimybių skirstiniai.

Trikdžio paveiktos sistemos modelyje kaip saugos barjerai veikia galutinès energijos generatoriai, kurie įsijungia nevei-

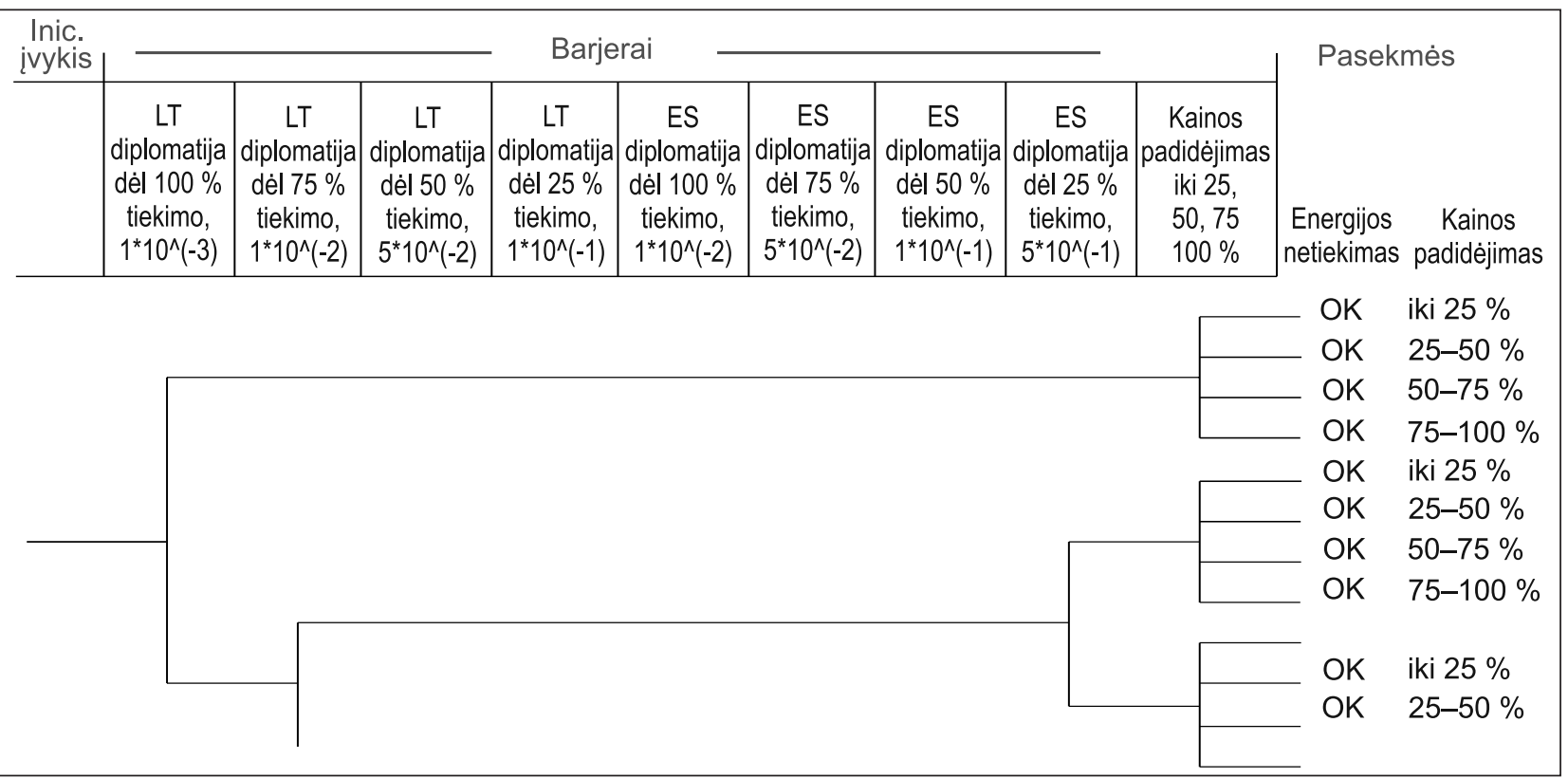

5 pav. Jvykių medžio fragmentas, kuriame iš grèsmių formuojamas trikdis ilgalaikis $100 \%$ dujų nutraukimas dèl geopolitinių priežasčių su šalimi tiekèja 
kiant pagrindinei sistemai, kai kuriems rezervinès sistemos generatoriams ar / ir kai nèra pagrindinio kuro, kai dèl ịvairių priežasčių nepavyksta suorganizuoti rezervinès gamybos.

Rezervinès sistemos - energijos generatoriai, energijos išteklių saugyklos, perdavimo ir paskirstymo tinklai turi dirbti papildomomis apkrovomis. Todèl vertinant energijos generatorius reikalingos šios jų patikimumą apibrèžiančios tikimybès:

1) generatoriaus, gaminančio energiją, naudojant alternatyvų kurą (pvz., jeigu vietoj nuolatos naudojamų gamtinių dujų, gamybai reikia mazuto), nepasileidimo tikimybė dèl organizacinių priežasčių (netiekiamas / neparuoštas kuras, žmogaus klaidos ir t. t.);

2) generatoriaus gedimo tikimybé;

3) generatoriaus gamybos alternatyviu kuru nesèkmès tikimybè.

Atskirų TE blokų ar katilinių gedimo tikimybẻ labai padidejja jiems senstant - senesnių generatorių patikimumas gali sumažèti iki kelių kartų.

Didelè dalis jẻgainių turi vienodą generatorių skaičių, todèl kai sèkmingam energijos tiekimui užtikrinti reika- lingas tik tam tikras generatorių kiekis, skaičiuojamas ju patikimumo sèkmès kriterijus. Dar vienas barjerų ịverčius patikslinantis metodas - tarpusavio priklausomybių analizé, naudojama alternatyvaus kuro tiekimui ịvertinti.

Čia objekto veikimui charakterizuoti naudojamas fizinis objekto parengtumas ir objekto išteklių prieinamumas bei objektų tarpusavio ryšiai.

Dèl priklausomybių tarp energetikos sistemos pavojingų objektų ir jų resursų, tiekejjai koreguoja mazuto tiekimo lygi ir tikimybę.

Pagrindinès tiesioginès energetinio saugumo pasekmès (galutinès būsenos) yra ịvairaus dydžio galutinès energijos netiekimas ar jos kainos padidejjimas (1 lentelè).

Atskiros pasekmių grupès gaunamos ilgalaikiams ir trumpalaikiams scenarijams. Itin retais atvejais trumpalaikis trikdis gali išprovokuoti ilgalaikes pasekmes.

Gaunami atitinkami galutinių būsenų skirstiniai. Tuomet gautų būsenų dažniai dauginami iš tiesinès pasekmių matricos (2 lentelè). Ši matrica pagal savo prigimtị galètų būti logaritminè - didejjant energetiniam nesaugumui, pasekmès svoris didejja.

1 lentelè. Galutinių būsenழ̨ aibè

\begin{tabular}{|c|c|c|c|c|c|c|c|}
\hline & & \multicolumn{6}{|c|}{ Kainų padidejjimas nuo prognozuojamų kainų \% } \\
\hline & & $0-25$ & $26-50$ & $51-75$ & 76-100 & 101 ir daugiau & $\begin{array}{l}\text { Vidutinis kainų } \\
\text { padidejjimo dažnis }\end{array}$ \\
\hline \multirow{11}{*}{$\begin{array}{c}\text { Nepateiktos } \\
\text { šilumos energijos } \\
\text { kiekis nuo bazinio } \\
\text { scenarijaus \% }\end{array}$} & OK & & & & & & \\
\hline & $1-10$ & & & & & & \\
\hline & $11-20$ & & & & & & \\
\hline & $21-30$ & & & & & & \\
\hline & $31-40$ & & & & & & \\
\hline & $41-50$ & & & & & & \\
\hline & $51-60$ & & & & & & \\
\hline & $61-70$ & & & & & & \\
\hline & $71-80$ & & & & & & \\
\hline & $81-90$ & & & & & & \\
\hline & $91-100$ & & & & & & \\
\hline $\begin{array}{r}\text { Vidutinis šilum } \\
\text { nutraukimy }\end{array}$ & $\begin{array}{l}\text { ekimo } \\
\text { nnis }\end{array}$ & & & & & & \\
\hline
\end{tabular}

2 lentelè. Pasekmių svorių matrica

\begin{tabular}{|c|c|c|c|c|c|c|}
\hline & $0-25$ & $26-50$ & $51-75$ & $76-100$ & 101 ir daugiau & \multirow{12}{*}{$\begin{array}{c}\text { Energetinio } \\
\text { saugumo } \\
\text { koeficientas }\end{array}$} \\
\hline OK & 1 & 0,75 & 0,5 & 0,25 & 0 & \\
\hline $1-10$ & 0,9 & 0,675 & 0,45 & 0,225 & 0 & \\
\hline $11-20$ & 0,8 & 0,6 & 0,4 & 0,2 & 0 & \\
\hline $21-30$ & 0,7 & 0,525 & 0,35 & 0,175 & 0 & \\
\hline $31-40$ & 0,6 & 0,45 & 0,3 & 0,15 & 0 & \\
\hline $41-50$ & 0,5 & 0,375 & 0,25 & 0,125 & 0 & \\
\hline $51-60$ & 0,4 & 0,3 & 0,2 & 0,1 & 0 & \\
\hline $61-70$ & 0,3 & 0,225 & 0,15 & 0,075 & 0 & \\
\hline $71-80$ & 0,2 & 0,15 & 0,1 & 0,05 & 0 & \\
\hline $81-90$ & 0,1 & 0,075 & 0,05 & 0,025 & 0 & \\
\hline \multirow[t]{2}{*}{$91-100$} & 0 & 0 & 0 & 0 & 0 & \\
\hline & & & & & & $\Sigma$ \\
\hline
\end{tabular}


Susumavus gaunamas energetinio saugumo koeficientas, skirtas palyginti skirtingus scenarijus.

\section{METODIKOS PRITAIKYMO PAVYZDYS}

Šiame skyriuje pateiktas anksčiau pristatytos metodikos pritaikymo pavyzdys - Kauno centralizuoto šilumos tiekimo (CŠT) sistemos plètros scenarijų energetinio saugumo palyginimas. Tai hipotetiniai Kauno CŠT plètros scenarijai.

Pagal energetiniam saugumui tirti sukurtą metodiką, pagrịstą energetinio saugumo analize, sudarytas Kauno CŠT sistemos modelis.

Skaičiavimai skirti nustatyti, kokią įtaką Kauno šilumos tiekimo sistemos energetiniam saugumui turi atsiradusi šilumos gamintojų rinka (gamyba sutelkta ne vienose rankose), o ne ịvertinti atskirus siūlomus techninius projektus.

Trikdžių susiformavimo modeliu vertintos bendros Lietuvos energetikos sistemai pavojingos grèsmès. Kainų padidejjimą arba/ir dujų tiekimo nutraukimą gali lemti šios grèsmès:

- dujų netiekimas ir/ar dèl Rusijos (tiekimo) arba Baltarusijos (tranzito) geopolitikos;

- dujų tiekimo nutraukimas ir/ar kainos padidèjimas dèl techninio gedimo dujų infrastruktūroje (importo ir / ar tiekimo linijų), dèl ekstremalių klimato sąlygų, dèl galimo terorizmo dujų tiekimo vamzdyne.

Grèsmès gali būti nukreiptos ị dujų netiekimo trikdị ar kainų padidèjimo trikdžius. Šiame darbe nagrinëjamas $100 \%$ duju netiekimo trikdis.

Ateityje būtų galima atsižvelgti ir į grèsmes, lemiančias kainų didejjimą: nusidèveję pastatai; taip pat aiškios, skaidrios, nuoseklios šilumos tiekimo politikos nebuvimas; atidèliojamas investavimo projektu igyvendinimas.

Kaip parodyta bendroje modelio schemoje (1 pav.), Kauno tikimybini modeli pirmiausia sudaro trikdžiu susiformavimo modelis. Po grèsmiu realizacijos susiformuoja trikdžiai. Vertinimas atliekamas tik dèl 1 trikdžio - ilgalaikio $100 \%$ duju tiekimo nutraukimo. Jis tampa inicijuojančiu įvykiu modeliuojant sutrikdytą Kauno CŠT sistemą.

Ilgalaikis scenarijus energetinio saugumo projektuose paprastai laikomas tokiu, kada gali būti igyvendinti energetikos sistemos infrastruktūrų renovacijos / įdiegimo darbai, t. y. pastatomi ar atnaujinami katilai, saugyklos, tiekimo vamzdžiai ar linijos.

Minètas trikdis suformuojamas iš labiausiai tikètinų anksčiau aptartų grèsmių. Gautas jo nutraukimų dažnis per metus yra apie 1,07E-03.

Toliau modeliuojama sutrikdyta Kauno šilumos sistema. Energetinio saugumo požiūriu Kauno (kaip ir visos Lietuvos) CŠT sistema yra uždara:

- pagrindinis šilumos gamintojas yra KTE. Vadinasi, miesto šilumos gamyba yra vienos įmonès rankose;
- Kauno termofikacinès elektrinès (KTE) įrenginių ir pagrindinio kuro - duju - tiekimas priklausomas nuo to paties savininko (UAB „Kauno termofikacijos elektrine““savininkas yra Rusijos dujų tiekimo bendrovè „Gazprom“).

Elektrinëje šilumą generuoja trys garo katilai po 290 MW, 4 vandens šildymo katilai po 116 MW, 209 MW katilas. Rezervinè yra Petrašiūnų elektrinė, Šilko, Pergalès ir Inkaro katilinès. Izoliuota šilumos tinklų zona yra išsidèsčiusi Aleksoto, Šančių, Panemunès bei Vilijampolès mikrorajonuose. Izoliuotame šilumos tiekimo tinkle pagaminama apie 8,2 \% visos Kauno šilumos energijos. Čia šiluma tiekiama iš nedidelès galios šilumos gamybos ịrenginių.

Kauno CŠT sistemoje šiluma gaminama naudojant vieną kurą - dujas. Daugelio katilinių rezervinis kuras yra mazutas, jis yra kaupiamas ir tam tikras jo kiekis net laikomas paruoštas naudoti (specialioje talpoje, atitinkamos temperatūros ir t.t.).

Kauno miesto maksimalus šilumos poreikis šildymo sezono metu 2010 m. buvo 600 MW, 2011 m. - 520 MW. Tokio dydžio poreikio Kauno miestui gali prireikti tik iki kelių savaičiu per metus (šilumos poreikis yra apie 350-370 MW). Scenarijai modeliuoti 500 MW šilumos poreikiui, kuris galimas atšiauriausiu žiemos sezonu. Todèl šie scenarijai yra sunkiai galimi.

Modeliuojamas laiko tarpsnis po $2016 \mathrm{~m}$., kai isigalios naujieji reikalavimai pagal Europos Parlamento ir Tarybos direktyvą 2010/75/ES dèl pramoniniu išmetamu teršalu - TIPK (Taršos integruotos prevencijos ir kontrolès) [10]. Ši direktyva reglamentuoja teršalu normas iš didelių (ne mažesnių kaip $50 \mathrm{MW}$ ) kurą deginančiu irenginių. Numatomos ir išimtys iki $2023 \mathrm{~m}$. tam tikras sąlygas tenkinančioms jègainèms. Pagal 2003 m. pasirašytą investiciju susitarimą su $\mathrm{AB}$ „Kauno energija“, ̨̧sipareigojusia nupirkti ne mažiau 80 \% šilumos poreikio Kauno integruotame šilumos tiekimo tinkle, KTE privalo per 15 metų investuoti i gamybos šaltinių statymą ir atnaujinimą ne mažiau kaip 400 mln. Lt.

Palyginimui modeliuoti šie ilgalaikiai plètros scenarijai esant vienam trikdžiui, t. y. visiškai nutraukus dujų tiekimą:

I scenarijus - KTE šilumos gamyba vyksta pagal 2010 m. instaliuotą galią, KTE nerekonstruota ir nepritaikyta 2016 m. isigaliosiantiems taršos reikalavimams;

II scenarijus - KTE papildomai instaliuotas $250 \mathrm{MW}$ biokuro katilas;

III scenarijus - KTE papildomai instaliuotas 200 MW biokuro katilas, LEZ - $200 \mathrm{MW}$ atliekų deginimo / biokuro katilas, Petrašiūnų TE rekonstruota, instaliuotas $150 \mathrm{MW}$ biokuro katilas (iš viso naujai instaliuota $550 \mathrm{MW}$ ). KTE lieka kaip rezervinè jègaine;

IV scenarijus - LEZ instaliuotas 200 MW atliekų deginimo/biokuro katilas, Petrašiūnu TE - $150 \mathrm{MW}$ biokuro katilas. Ne KTE savininko nuosavybèje (Šilko, Pergalès arba 
Inkaro katilinių teritorijoje) instaliuotas $100 \mathrm{MW}$ dujų katilas bei du biokuro katilai po $50 \mathrm{MW}$ (iš viso naujai instaliuota $550 \mathrm{MW}$ ). KTE lieka kaip rezervinè jègainè.

Daroma prielaida, kad katilų gamybos naudingumas yra 0,9 .

Visose jėgainėse numatytas atsarginis kuras: biokuro jègainèse atsarginis yra kietasis kuras, dujų jėgainèse - mazutas.

Modelyje (vertinant gedimo tikètinumą) atsižvelgiama i jègainių amžių, gamybos nesèkmes dèl skirtingo kuro, tikimybinę gamybą organizuoti rezerviniu kuru (pvz., realiai gali būti, kad mazutas nèra paruoštas energijos gamybai ir pan.).

Vertinant kainų didejimo tikètinumą atsižvelgiama ị tai, kiek įmonių gamina šilumą (konkurencijos ar monopolijos sąlygomis). Be to, jei jègainès nebus rekonstruotos pagal ES 2016 m. direktyvos reikalavimus, dèl numatomų sankcijų ir kt. priežasčių yra didele tikimybė, kad šilumos kaina po 2016 m. padidès daugiau nei $100 \%$.

I scenarijaus supaprastintas ịvykių medžio fragmentas yra parodytas 6 pav. Jame vienas po kito išvardinti atskiri katilai, kurie galètų dirbti, kai, nutraukus dujų tiekimą, ši- lumos gamyba organizuojama pasitelkus mazutą. Šių katilų darbas vertinamas kaip galima gamybos alternatyva ir darbui jų jungiama tiek, kad patenkintų poreikį.

Galimos dvi kiekvienos ịvykių eigos pasekmès su skirtingom tikimybėm, kurios nustatomos modeliu (pradiniai duomenys nustatomi statistiškai): Kauno šilumos netiekimo procentinè dalis ir kaina (6 pav. parodyti tik netiekimo pasekmių dažniai).

Pagal kiekvieną scenarijų gaunamos ilgalaikių galutinių būsenų dažnių per metus lentelès (skaičiuojama pagal 2010 m. duomenis; (8) formulè).

3 lentelèje pateikti rezultatai, gauti pagal I scenarijų. Dèl kylančių kainų modeliuojant išskirtos tik dvi kainų didejjimo būsenos: padidejja 26-50 \% arba 51-100\%.

Palyginti su I scenarijumi, rinkos scenarijaus (IV) atveju gautos netiekimo ar kainos didejjimo tikimybès yra mažesnès (4 lentelè).

Tiek didesnès, tiek mažesnès apimties energijos tiekimo nutraukimai mažiau tikètini naujose jègainèse (7 pav.). Taip pat galima pastebėti, kad tiekimo nutraukimų kreivès kinta laipsniškai: iš pradžių staigiai krenta, o po to - pamažu.

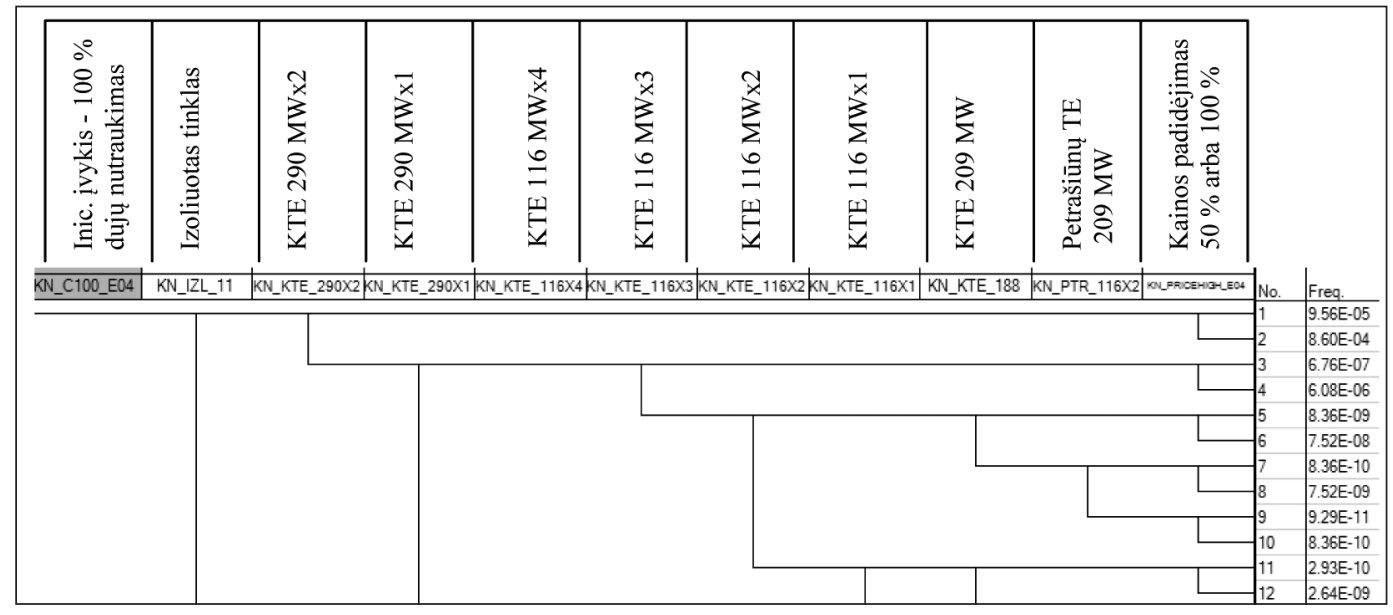

6 pav. I scenarijaus supaprastintas j̣vykių medžio fragmentas

3 Ientelè. Ilgalaikių galutinių būsenų aibès dažniai per metus pagal 2010 m. duomenis (I scenarijus)

\begin{tabular}{|c|c|c|c|c|}
\hline & & \multicolumn{3}{|c|}{ Kainų padidèjimas nuo prognozuojamų kainų \% } \\
\hline & & $26-50$ & $51-100$ & $\begin{array}{c}\text { Vidutinis kainų } \\
\text { padidèjimo dažnis }\end{array}$ \\
\hline \multirow{11}{*}{$\begin{array}{l}\text { Nepateiktos šilumos } \\
\text { energijos kiekis nuo } \\
\text { bazinio scenarijaus \% }\end{array}$} & OK & $2,42 \mathrm{E}-04$ & $1,05 E-03$ & \multirow{12}{*}{$1,25 \mathrm{E}-01$} \\
\hline & $1-10$ & $2,90 \mathrm{E}-05$ & $2,42 \mathrm{E}-04$ & \\
\hline & $11-20$ & $1,40 \mathrm{E}-10$ & $1,25 E-09$ & \\
\hline & $21-30$ & $5,26 \mathrm{E}-12$ & $4,73 \mathrm{E}-11$ & \\
\hline & $31-40$ & $2,41 \mathrm{E}-1$ & $2,16 \mathrm{E}-10$ & \\
\hline & $41-50$ & $1,05 \mathrm{E}-13$ & $9,43 E-13$ & \\
\hline & $51-60$ & $1,82 \mathrm{E}-12$ & $1,64 \mathrm{E}-11$ & \\
\hline & $61-70$ & $7,52 \mathrm{E}-15$ & $6,77 \mathrm{E}-14$ & \\
\hline & $71-80$ & $6,35 \mathrm{E}-14$ & $5,72 \mathrm{E}-13$ & \\
\hline & $81-90$ & & & \\
\hline & $91-100$ & \multicolumn{2}{|c|}{$8,36 \mathrm{E}-15$} & \\
\hline \multicolumn{2}{|c|}{ Vidutinis šilumos tiekimo nutraukimų dažnis } & \multicolumn{2}{|c|}{$1,36 \mathrm{E}-03$} & \\
\hline
\end{tabular}


4 lentelè. Ilgalaikių galutinių būsenų aibės dažniai per metus pagal $2010 \mathrm{~m}$. duomenis (IV scenarijus)

\begin{tabular}{|c|c|c|c|c|c|c|}
\hline & & \multicolumn{5}{|c|}{ Kainų padidèjimas nuo prognozuojamų kainų \% } \\
\hline & & $0-25$ & $26-50$ & $51-75$ & $76-100$ & $\begin{array}{l}\text { Vidutinis kainŭ } \\
\text { padidejjimo dažnis }\end{array}$ \\
\hline \multirow{11}{*}{$\begin{array}{l}\text { Nepateiktos šilumos } \\
\text { energijos kiekis nuo } \\
\text { bazinio scenarijaus\% }\end{array}$} & $\mathrm{OK}$ & $8,26 \mathrm{E}-04$ & $3,27 \mathrm{E}-05$ & $3,27 \mathrm{E}-05$ & $6,59 \mathrm{E}-07$ & \multirow{12}{*}{$1,55 \mathrm{E}-02$} \\
\hline & $1-10$ & $1,04 \mathrm{E}-04$ & 4,77E-06 & $4,77 \mathrm{E}-06$ & $7,32 \mathrm{E}-08$ & \\
\hline & $11-20$ & $2,68 \mathrm{E}-14$ & $6,86 \mathrm{E}-14$ & $6,86 \mathrm{E}-14$ & $6,46 \mathrm{E}-15$ & \\
\hline & $21-30$ & $5,22 \mathrm{E}-15$ & $4,32 \mathrm{E}-14$ & $4,32 \mathrm{E}-14$ & $4,30 \mathrm{E}-15$ & \\
\hline & $31-40$ & $3,38 \mathrm{E}-16$ & $5,15 \mathrm{E}-15$ & $5,15 \mathrm{E}-15$ & $5,39 \mathrm{E}-16$ & \\
\hline & $41-50$ & $6,45 \mathrm{E}-17$ & $1,84 \mathrm{E}-15$ & $1,84 \mathrm{E}-15$ & $1,89 \mathrm{E}-16$ & \\
\hline & $51-60$ & & $2,28 \mathrm{E}-16$ & $2,28 \mathrm{E}-16$ & $2,49 \mathrm{E}-17$ & \\
\hline & $61-70$ & & $3,28 \mathrm{E}-17$ & $3,28 \mathrm{E}-17$ & $3,44 \mathrm{E}-18$ & \\
\hline & $71-80$ & & $5,18 \mathrm{E}-18$ & $5,18 \mathrm{E}-18$ & $5,76 \mathrm{E}-19$ & \\
\hline & $81-90$ & & $1,79 \mathrm{E}-19$ & $1,79 \mathrm{E}-19$ & $1,99 \mathrm{E}-20$ & \\
\hline & $91-100$ & $5,22 \mathrm{E}-20$ & & & & \\
\hline $\begin{array}{r}\text { Vidutinis šilum } \\
\text { nutraukim }\end{array}$ & $\begin{array}{l}\text { kimo } \\
\text { his }\end{array}$ & \multicolumn{4}{|c|}{$5,68 \mathrm{E}-04$} & \\
\hline
\end{tabular}

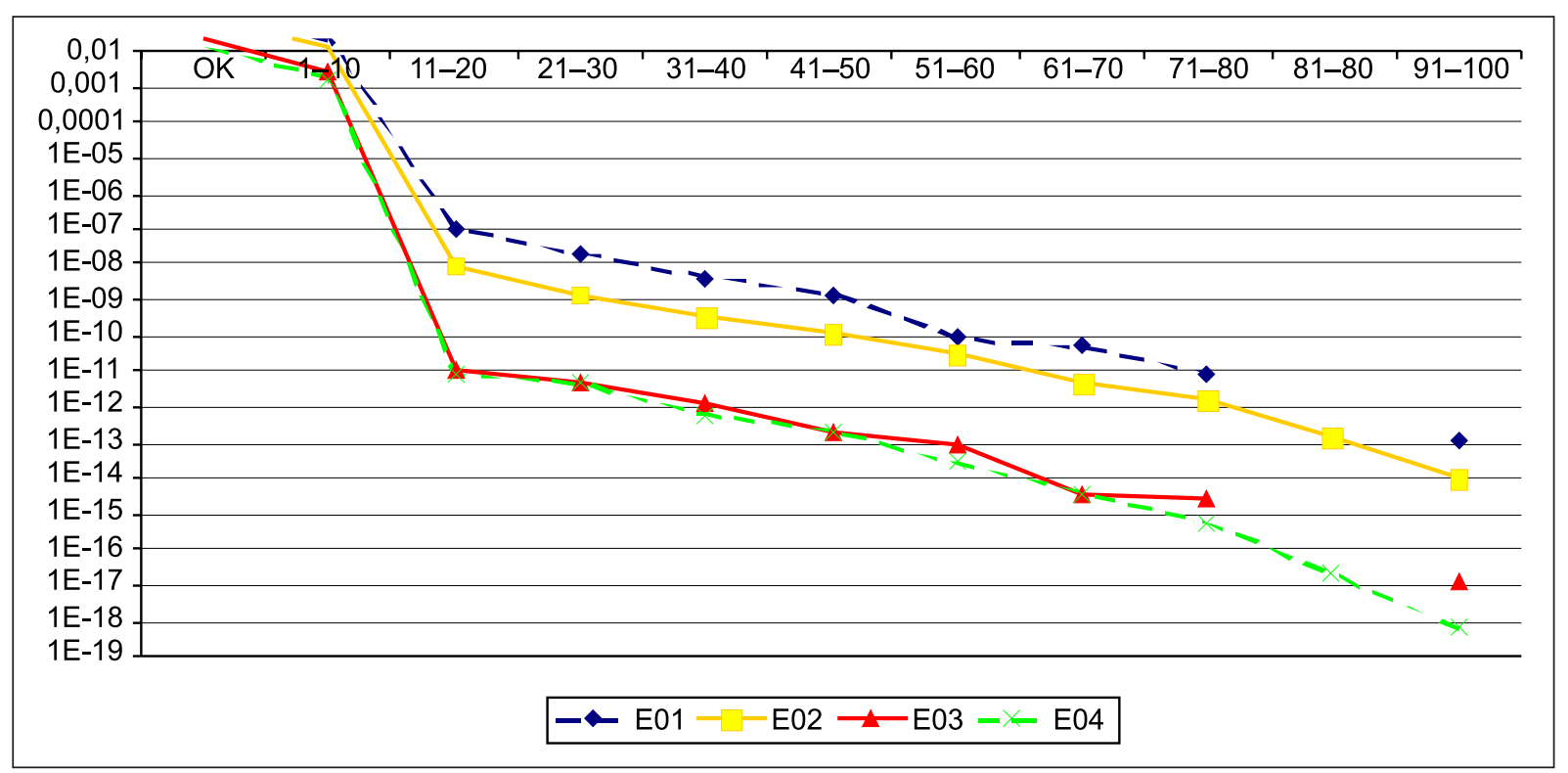

7 pav. Kauno šilumos nutraukimo dažnių kreivės, 100 \% nutraukus dujų tiekimą (skirtingi scenarijai)

Kainų padidejimas po 2016 m. taip pat mažiausiai tikètinas tais atvejais, kai yra pasiruošta vykdyti direktyvas dèl teršalų. Lyginant III ir IV scenarijus, visiškai nutraukus dujų tiekimą, pastarajame mažiau tikètinas labai didelis kainos šuolis, nes čia gamyba nèra sutelkta vienose rankose, nors iš esmès abiejuose scenarijuose visiškai patenkinama gamybos paklausa naudojant naujas jègaines.
5 lenteleje pateiktas energetinio saugumo koeficientas, apskaičiuotas pagal sukurtą metodologiją. Pagal ši rodiklį bei energijos netiekimą ir kainų padidejjimą (daugiau nei $25 \%$ tikimybè) galima palyginti modeliuotus Kauno šilumos tiekimo scenarijus (pagal energetinio saugumo rodiklius) (5 lentelè).

Scenarijai, kai pasirenkama strategija eksploatuoti tuos pačius įrengimus, neatitinkančius taršos reikalavimų, arba

5 lentelè. Scenarijų palyginimas pagal energetinio saugumo rodiklius

\begin{tabular}{|c|c|c|c|c|}
\hline & Scen I & Scen II & Scen III & Scen IV \\
\hline Energetinio saugumo koeficientas & 33 & 59 & 91 & 96 \\
\hline Energijos netiekimo tikimybè & 0,173 & 0,137 & 0,105 & 0,113 \\
\hline $\begin{array}{c}\text { Kainu padidejjimo daugiau } \\
\text { nei } 25 \% \text { tikimybè }\end{array}$ & 1 & 1 & 0,299 & $7,52 \mathrm{E}-02$ \\
\hline
\end{tabular}


termofikacinèje elektrinėje instaliuoti 1 jègainę, kuri nepatenkina visos šaltojo sezono paklausos, nusileidžia kitiems tiek pagal didẻjančias kainas, tiek pagal galimą energijos netiekimą.

Aukščiausi energetinio saugumo koeficientai, kurie tarpusavyje mažai skiriasi, gauti pagal III ir IV scenarijus, kur analizuojamas naujų, tenkinančių taršos reikalavimus po 2016 m., irrenginių instaliavimas. IV scenarijus yra pranašiausias dèl mažiausiai didèjančių kainų (tikimybẻ mažesnẻ daugiau kaip 13 kartų). Mažesnị kainų didèjimą daugiau nei $25 \%$ lemia rinkos sąlygų padiktuota konkurencija, šilumos gamybai naudojamas biokuras (šaltuoju metų sezonu kuro kaina sudaro apie $1 / 3$ šilumos kainos). Tačiau IV scenarijus patikimumu labai mažai nusileidžia III scenarijui, kur modelyje parinktos didesnès jègainès (tokios jègainès labiau tikètinos, kai valdymas sutelktas vienose rankose: lengviau rasti investiciju jų statymui, sutelkti pajègas administravimui). Kai statomos didesnès jègainès vietoj mažesnių, o išlaikomas toks pat bendras galingumas, patikimumas yra šiek tiek didesnis (5 lentelè), nes techniškai gedimo tikimybè yra didesnè ten, kur ịrenginių daugiau. Kai įrenginiai didesni, sugedus vienam iš jų, patiriama daugiau praradimų tiek tiekimo, tiek finansinių nuostoliu prasme. Beje, taip parinktuose scenarijuose nèra atsakymo ị klausimą, kuris kuras - biokuras ar dujos - yra geresnis energetinio saugumo požiūriu.

Reikia pastebèti, kad metodikoje naudojamos barjeru suveikimo tikimybès nèra labai tiksliai ịvertintos dèl nedidelès statistinių duomenų apimties, iki galo nežinomų visų aplinkybių ir kt. Tai didina galutinių rezultatų neapibrèžtumą. Tačiau taikant šią metodiką skirtingų plètros scenarijų palyginimui, t. y. vartojant santykines charakteristikas, neapibrèžtumas yra gerokai sumažinamas.

\section{REZULTATAI IR IŠVADOS}

1. Straipsnyje pateikta tikimybinès saugumo analizės metodika, apimanti energetikos sistemos grèsmių analizę, energetikos sistemos trikdžių susiformavimo modelį ir trikdžių vystymosi scenarijų modelį. Metodika leidžia atlikti ịvairių energetikos sistemos plètros scenarijų analizę, palyginti jų energetinị saugumą.

2. Sukurta metodika energetinio saugumo koeficientui skaičiuoti. Šis koeficientas ịvertina energijos kainų kilimą ir nepatiektos energijos kiekị.

3. Metodikos taikymas paremtas Kauno CŠT sistemos scenariju analize. Esant visiškam duju nutraukimui buvo lyginami keturi Kauno aprūpinimo šiluma plètros scenarijai po $2016 \mathrm{~m}$.: I - kai eksploatuojami tie patys įrengimai, neatitinkantys taršos reikalavimų; II - kai KTE papildoma 250 MW biokuro jègaine išlaikant vieną savininką; III - kai KTE, LEZ, Petrašiūnu TE instaliuojamos stambios biokuro jègainès, patenkinančios šaltojo sezono poreikius, rezervi- niais lieka senos KTE jejgainės; IV - instaliuojamos rinkos principu veikiančios smulkios biokuro ir dujų jëgainès, patenkinančios šaltojo sezono poreikius, o rezerve lieka senos KTE jėgainès. Nustatyta, kad energetinis saugumas geriausiai užtikrinamas pagal rinkos modelį (energetinio saugumo koeficientas yra 97), toliau atitinkamai eina III, II ir I scenarijai $(91,59,33)$.

4. Suminio kainų padidèjimo tikimybè daugiau nei $25 \%$ pagal I ir II scenarijus yra artima vienetui (nors II atveju kainų didèjimo daugiau nei $50 \%$ tikimybè yra didesnè 1,21 karto), t. y. labai tikètina, kad kaina pagal I ir II scenarijus kils; III - mažesnè 3,34 karto, palyginti su I scenarijumi; IV - net 13,30 kartų, palyginti su I scenarijumi.

5. Bet kokio dydžio energijos netiekimo tikimybè (lyginama su I scenarijumi, kai papildomai nieko neinstaliuojama) II scenarijaus sumažeja 1,26 karto, III - 1,65 karto, IV - 1,53 karto. Priežastis - papildomai instaliuojamos naujos patikimesnès jègainès. Tarpusavyje lyginant scenarijus, kai instaliuojamos vienodo galingumo jëgainès (III ir IV), patikimiau, kai instaliuojamos didesnès galios jègainès.

6. Kauno aprūpinimo šiluma tinkamiausias šilumos tiekimo modelis (pagal energetinị saugumą) yra rinkos modelis (IV scenarijus).

\section{PADÉKA}

Tyrimą finansavo Lietuvos mokslo taryba (sutarties Nr. ATE-06/2012).

Gauta 20120412 Priimta 20120627

\section{Literatūra}

1. Suzuki T., Hippen D. V. A framework for energy security analysis and application to a case study of Japan. Synthesis Report for the Pacific Asia Regional Energy Security (PARES) Project, Phase 1, 1998.

2. Energijos tiekimo galimybes Lietuvai - detali daugiasektorine integruota energijos paklausos, pasiülos ir aplinkosaugos analize. TATENA, 2004.

3. Molis A. Lietuvos geoenergetinio saugumo politikos gaires ir Lietuvos geoenergetiniu alternatyvu paieškos trumpuoju ir vidutiniu laikotarpiu. Vilnius: Strateginiu studiju centras, 2006.

4. Molis A. Lietuvos galimybes diversifikuoti duju tiekima: pagrindines kliūtys. Vilnius: Strateginių studijų centras, 2007.

5. Gnansounou E. Monitoring the vulnerability of energy supply system. Proceedings of 15th Energy Day in Croatia - Energy Policy Scenarios for 2050, Zagreb, Croatia, 2006. 
6. Loschel A., Moslener U., Rubbelke D. T. G. Indicators of energy security in industrialised countries, Energy Policy. 2010. Vol. 38. No. 4. P. 1665-1671.

7. Cohen G., Joutz F., Loungani P. Measuring energy security: Trends in the diversification of oil and natural gas supplies. Energy Policy. 2011. Vol. 39. No. 9. P. 48404869.

8. Colli A. A Methodology to Allow Comparison among Different Energy Systems: PhD thesis, TUDelft, 2009.

9. WASH-1400. Reactor Safety Study, U. S. Nuclear regulatory Commission, NUREG-75/014 1975.

10. Europos parlamento ir tarybos direktyva 2010/75/ES $2010 \mathrm{~m}$. lapkričio $24 \mathrm{~d}$. dèl pramoninių išmetamų teršalų (taršos integruotos prevencijos ir kontrolès) (nauja redakcija). http://eur-lex.europa.eu/LexUriServ/LexUriServ.do?uri= OJ:L:2010:334:0017:0119:1t:pdf

Juozas Augutis, Vaida Matuzienè

\section{PROBABILISTIC ASSESSMENT OF ENERGY SECURITY. ANALYSIS OF KAUNAS HEAT SUPPLY MARKET}

Summary

The aim of the paper is to present probabilistic energy security methodology that allows to analyse the impact of various risk (technical, economic, socio-political) consequences on energy security.

The methodology is presented in two parts: the formation of disturbance from the threat model and the disrupted energy system development model.

The calculations are made on the basis of the probabilistic safety analysis.

The paper presents a general energy system model, describes elements of its concept (threat realization, disturbance, barrier, consequence) and introduces assessment indicators of energy system consequences after threat realization.

The company Kaunas Energy is chosen for the demonstration of the method. A few hypothetical system development scenarios for one disturbance - full gas supply disruption - are researched. The scenarios cover a wide range of investments into the supply of heat - both in the reconstruction of Kaunas CHP plant and construction of biomass boilers. According to the created technology, different heating supply development scenarios are compared among each other and advantages of free heat production market are shown.

Key words: energy, energy security, probabilistic analysis
Юозас Аугутис, Вайда Матузене

\section{ВЕРОЯТНОСТНАЯ ОЦЕНКА ЭНЕРГЕТИЧЕСКОЙ БЕЗОПАСНОСТИ. АНАЛИЗ РЫНКА ТЕПЛОСНАБЖЕНИЯ КАУНАСА}

Резюме

Статья предназначена для представления созданной вероятностно энергетической безопасности методологии, что позволяет анализировать последствия воздействия энергетической безопасности различных рисков (технические, экономические, социально-политические).

Методология представлена в двух частях: модели формирования нарушения от угрозы и модели развития нарушенной энергетической системы.

Расчеты сделаны на основе вероятностного анализа безопасности.

В данной статье представлена общая модель энергетической системы, объясняются элементы её концепции (реализация угрозы, нарушения, барьеры, последствия), введены индикаторы оценки последствия энергосистемы после реализации угрозы.

Для демонстрации разработанного метода выбрана компания „Кауно энергия“. Сделан анализ нескольких гипотетических сценариев развития системы на единичный случай - полное прекращение снабжения газа. Сценарии охватывают широкий спектр методов инвестиций в теплоснабжение - как реконструкцию Каунасской ТЭЦ, так и строительство котельных биомассы. В соответствии с разработанным методом, различные сценарии развития теплоснабжения Каунаса сравнены друг с другом, показано преимущество производство тепла свободного рынка.

Ключевые слова: энергетика, энергетическая безопасность, вероятностный анализ 